\title{
Relationship between slaughter weight and growth as well as carcass traits in creole pigs
}

\author{
I. CANOPE *, Y. RAYNAUD ** \\ $\because$ I.N.R.A., Station de Recherches zootechniques, \\ Centre des Antilles-Guyane, 97170 Petit-Bourg, Guadeloupe \\ *: Union Coopérative Agricole de la Marne, \\ Saint-Martin-sur-le-Pré, F 51100 Châlons-sur-Marne
}

The relationship between slaughter weight and growth and the carcass traits was studied with a sample of 63 growing pigs of the local breed (Creole) reared in Guadeloupe (F.W.I.). The three pre-determined weights were 65,75 and $85 \mathrm{~kg}$.

In the weight intervals $24-65,24-75$ and $24-85 \mathrm{~kg}$, daily mean gain $(425,426,441 \mathrm{~g}$, respectively) and food conversion ratio $(3.8,3.9,4.1)$ were not affected by slaughter weight.

However, a significant sex effect was observed with a superiority of the castrated males of 9,16 and 7 p. 100 for daily mean gain and 7,11 and 6 p. 100 for food conversion ratio.

The best growth performance was obtained in the 75-85 $\mathrm{kg}$ interval for the females (503) and in the $65-75 \mathrm{~kg}$ for the castrated males (553) and for castrated males + females (478 $\mathrm{g})$. No significant effect was observed in the latter case.

Carcass quality and body composition depending on slaughter weight showed the following characteristics :

- A better percentage of lean $(41.9$ p. 100) in the carcass of pigs slaughtered at $65 \mathrm{~kg}(\mathrm{P}<0.01)$;

- An increase with slaughter weight of the proportion of fat in carcasses up to $75 \mathrm{~kg}$ (from 36.4 p. 100 to 41.6 p. 100 ) ;

- An increasing loin/backfat ratio with decreasing slaughter weight $(1.67$ at $65 \mathrm{~kg}$ vs 1.38 at $85 \mathrm{~kg}$ ).

\section{Comparative studies of different ultra sound devices for measuring backfat thickness on live animals}

\author{
J. NAVEAU *, G. GODET **, G. ROLLAND*, D. FRANCOIS *** \\ * Société civile agricole Pen Ar Lan, \\ B.P. $n^{\circ}$ 3, Maxent, F 35380 Plelan-le-Grand \\ *I.T.P. Région Ouest. \\ B.P. $n^{\circ}$ 3, La Motte-au-Vicomte, $F 35650$ Le Rheu \\ *** Stagiaire E.N.S.A. de Rennes auprès de l'I.T.P. Région Ouest
}

Two studies were made to compare the accuracy of various devices used to measure backfat thickness on live pigs. The following conclusions can be drawn.

- The cathodic echographes (types $1002 \mathrm{P}$ or $1003 \mathrm{P}$ of KARL Deutsch) are highly reliable for measuring backfat thickness in live animals, but they have to be manipulated by qualified operators;

- The accuracy of the lean meater of the firm Renco is similar or comparable to that of the previous devices. Users attention should be drawn upon the fact that measurements at the level of the loin are difficult and can only be made before to that site or at the level of the stifle. This instrument can easily be used by any operator without previous training,

- The prototype of the firm Socomate (diode screen), like the echographes permit to visualize the structure of the fat layer. The level of performance is rather good. 